\title{
5 - Animal model of the abdominal compartment syndrome as a single insult and as a second insult in rats ${ }^{1}$
}

\author{
João Baptista de Rezende-Neto ${ }^{2}$ \\ Alcino Lázaro da Silva ${ }^{3}$ \\ José Renan Cunha-Melo ${ }^{3}$
}

\begin{abstract}
Rezende-Neto JB, Silva AL, Cunha-Melo JR. Animal model of the abdominal compartment syndrome as a single insult and as a second insult in rats. Acta Cir Bras [serial online] 2003 Vol 18 Special Edition. Available on URL: http://www.scielo.br/acb.

ABSTRACT - The objective of this paper was to develop a clinically relevant abdominal compartment syndrome experimental model, as a single insult and as a second insult flowing hemorrhagic shock. In the single insult model, Sprague-Dawley male-rats are anesthetized, invasively monitored (central venous pressure and mean arterial pressure), and mechanically ventilated during intraperitoneal injection of air to provoke the abdominal compartment syndrome (25 mmHg) for 60 minutes. In the two insult model, Sprague-Dawley male-rats are anesthetized, invasively monitored (mean arterial pressure) and bled to a mean arterial pressure of $30 \mathrm{mmHg}$ for 45 minutes. Fluid resuscitation is accomplished by infusing $0.9 \%$ sodium chloride solution $(0.9 \%$ $\mathrm{NaCl}) 33.2 \mathrm{ml} / \mathrm{kg}$ plus $75 \%$ of shed blood volume. During this phase a laparotomy is performed. Two hours after the beginning of the hemonhagic shock phase the animals are anesthetized, intubated (onotracheal), mechanically ventilated (mean arterial pressure), and the intra-abdominal pressure is increased to $25 \mathrm{mmHg}$ for 60 minutes, as a second insult. A $0.9 \% \mathrm{NaCl}$ solution is infused during this phase $(45 \mathrm{ml} / \mathrm{kg} / \mathrm{h})$. Hemornhagic shock and the abdominal compartment syndrome behave as clinically relevant additive insults.
\end{abstract}

KEY WORDS - Animal model. abdominal compartment syndrome. Inflammatory response. Lung injury. Multiple organ failure.

\section{Introduction}

The abdominal compartment syndrome (ACS), defined as an elevated intra-abdominal pressure at a sufficient level to produce an adverse physiologic response, is a known complication of traumatic and nontraumatic surgery and important confounder of surgical intensive care following trauma. ${ }^{1,2,3,5}$ Respiratory derangement caused by elevated intra-abdominal pressure has been known since the late 1800's, and the deleterious effects of intra-abdominal hypertension (IAH) on other organ systems were recognized in the early 1900's. ${ }^{6,7}$ To this date it has been demonstrated that practically all organs are affected by the ACS, except for the adrenal glands. ${ }^{1,2,3}$ Although intra-abdominal pressure of $25-35 \mathrm{mmHg}$ have been recognized as a potential for the development of ACS, there is still no consensus as to what is the critical intra-abdominal pressure. ${ }^{1,2,3}$ In a recent clinical study of damage control laparotomy, early ACS emerged as an independent risk factor for

1. Faculty of Medicine Federal University of Minas Gerais. Brazil.

2. Assistent Professor - Surgery Departament of Faculty of Medicine - Federal Univensity of Minas Gerais.

3. Head of Digestive Surgery - Surgery Departament of Faculty of Medicine - Federal University of Minas Gerais. 
postinjury multiple organ failure (MOF). ${ }^{8}$ Furthermore, hemonthagic shock facilitates the occurrence of ACS. In the two-event model of MOF, the first insult primes the inflammatory cascade, creating a vulnerable window to secondary insults capable of activating the system and precipitating late MOF. ${ }^{9}$ It has recently been shown, in a rodent model, that the ACS induces the systemic release of pro-inflammatory cytokines (Interleukin (IL-1, IL-6, $\mathrm{TNF} \alpha$ ) which may become critical in serving as a second insult for the induction of post-injury MOF. ${ }^{10}$

\section{Proposition}

A limiting factor for advance in the pathogenesis of multiple organ failure (MOF) research is the lack of clinically relevant animal models capable of simulating on the bench the severe insults seen on clinical practice. ${ }^{10}$ To fulfill that necessity, two experimental models are described in this paper. The first model refers to the ACS as a single insult, whereas the second model was designed to simulate a critically ill hemorrhagic shock patient under volume resuscitation, surgical intervention (laparotomy) followed by a post-operative complication, the ACS. These models should serve not only to determine the physiologic derangement caused by the ACS but also as tools forfurther systemic inflammatory response syndrome research.

\section{Method description - Abdominal Compartment Syndrome as a Single Insult}

\section{Animals}

Male Sprague-Dawley rats weighing between 250-300g

\section{Anesthesia}

Pentobarbital sodium, $50 \mathrm{mg} / \mathrm{kg}$ administered intraperitoneally.

\section{Body Temperature}

Rectal temperature is maintained between $37-38^{\circ} \mathrm{C}$ throughout the procedure with a heating lamp.

\section{Skin Antisepsis}

Surgical sites are prepared with antiseptic bactericidal solution.

\section{Local Anesthesia}

Surgical sites are injected with $1 \%$ lidocaine $(0,5 \mathrm{ml})$.

\section{Surgical Procedure}

Under aseptic technique a $7 \mathrm{~mm}$ longitudinal cervical incision exposes the trachea which is lifted by two 4-0 silk stay sutures. A $1.5 \mathrm{~cm}$ long angiocath (14G) is introduced into the trachea through a $2 \mathrm{~mm}$ incision on the anterior aspect of the trachea. The right jugular vein is exposed through a $5 \mathrm{~mm}$ longitudinal cervical incision and cannulated with a previously heparinized polyethylene tubing (PE50) $10 \mathrm{~cm}$ long. The catheter is tied over the vein with stay sutures. The incision is closed with a single 5-0 nylon stitch. Access to the left common carotid artery is obtained using the same method described above.

\section{Access to the Abdominal Cavity}

The abdominal cavity is accessed at two different sites. Firstly an angiocath (20G) is positioned (percutaneous) into the abdominal cavity, on the lower third, to the right of the midline. Another catheter 
(angiocath 20G) is positioned in the same manner to the left of the midline. This catheter is connected to a 0.45 $\mu \mathrm{m}$ air filterand a three way intravenous injection device (Figure 1).

\section{Monitoring}

The right jugular vein catheter and the left carotid artery catheter are individually connected to a pressure transducer for continuous monitoring of the central venous pressure (CVP) and the mean arterial pressure (MAP). Data is shown on a personal computer screen using specific software. Intra-abdominal pressure is continuously assessed through the right intra-abdominal catheter connected to an individual pressure transducer. Baseline MAP, CVP and intra-abdominal pressure are assessed for 5 minutes before provoking the ACS.

\section{Mechanical Ventilation}

After baseline measurements the endotracheal catheter is connected to a rodent mechanical ventilator set for 60 breaths per minute and tidal volume of $1.5 \mathrm{ml} / 100 \mathrm{~g}$ of body weight. New baseline values are obtained for 5 minutes. To assess the isolated effects of the ACS, no intravenous fluids are given to the animals in during the period of HIA
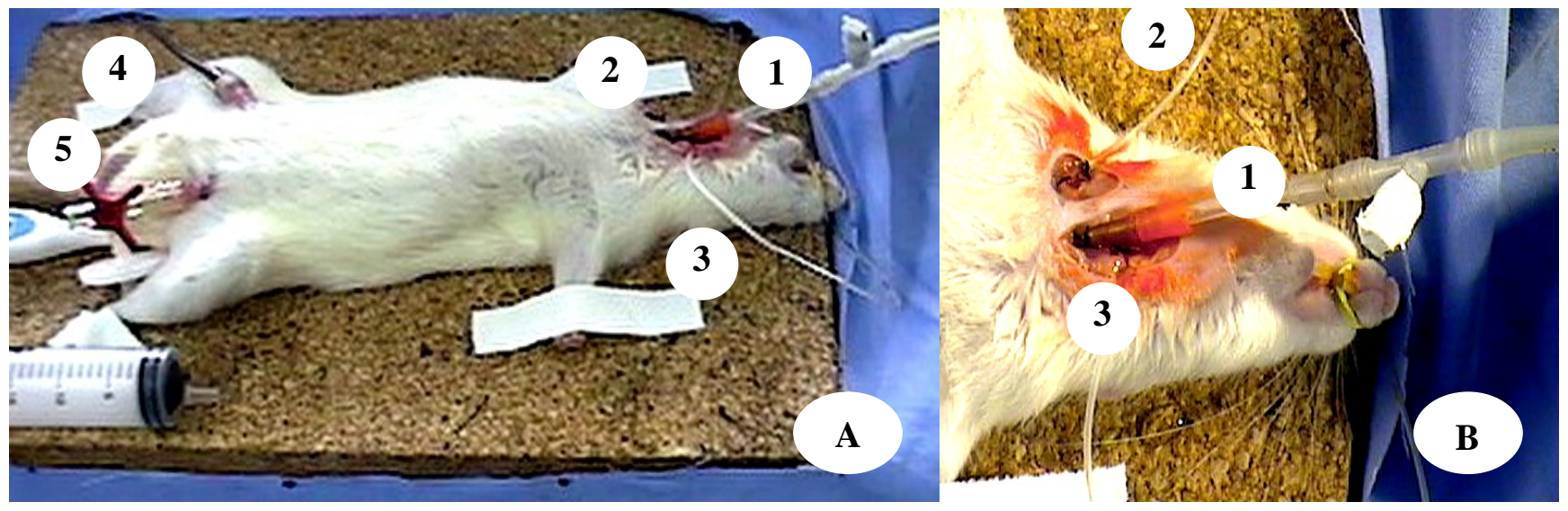

FIGURE 1 - Surgical preparation of the animal in the ACS model. In A: 1- Tracheostomy; 2- Right jugular vein intravenous catheter, 3- Left carotid artery catheter, 4- Right intra-peritoneal catheter, 5- Left intrapenitoneal catheter; Arrow - Air filter, In B: Close up view of A.

\section{Intra-abdominal hypertension}

Intra-abdominal pressure is initially increased to $10 \mathrm{mmHg}$ by manual injection of room air, with a 20 ml syringe connected to the catheter on the midline. After 10 minutes more air in injected, in the same manner, until the final intra-abdominal pressure of $25 \mathrm{mmHg}$ is achieved (Figure 2). Continuous hemodynamic monitoring is maintained throughout the procedure. 


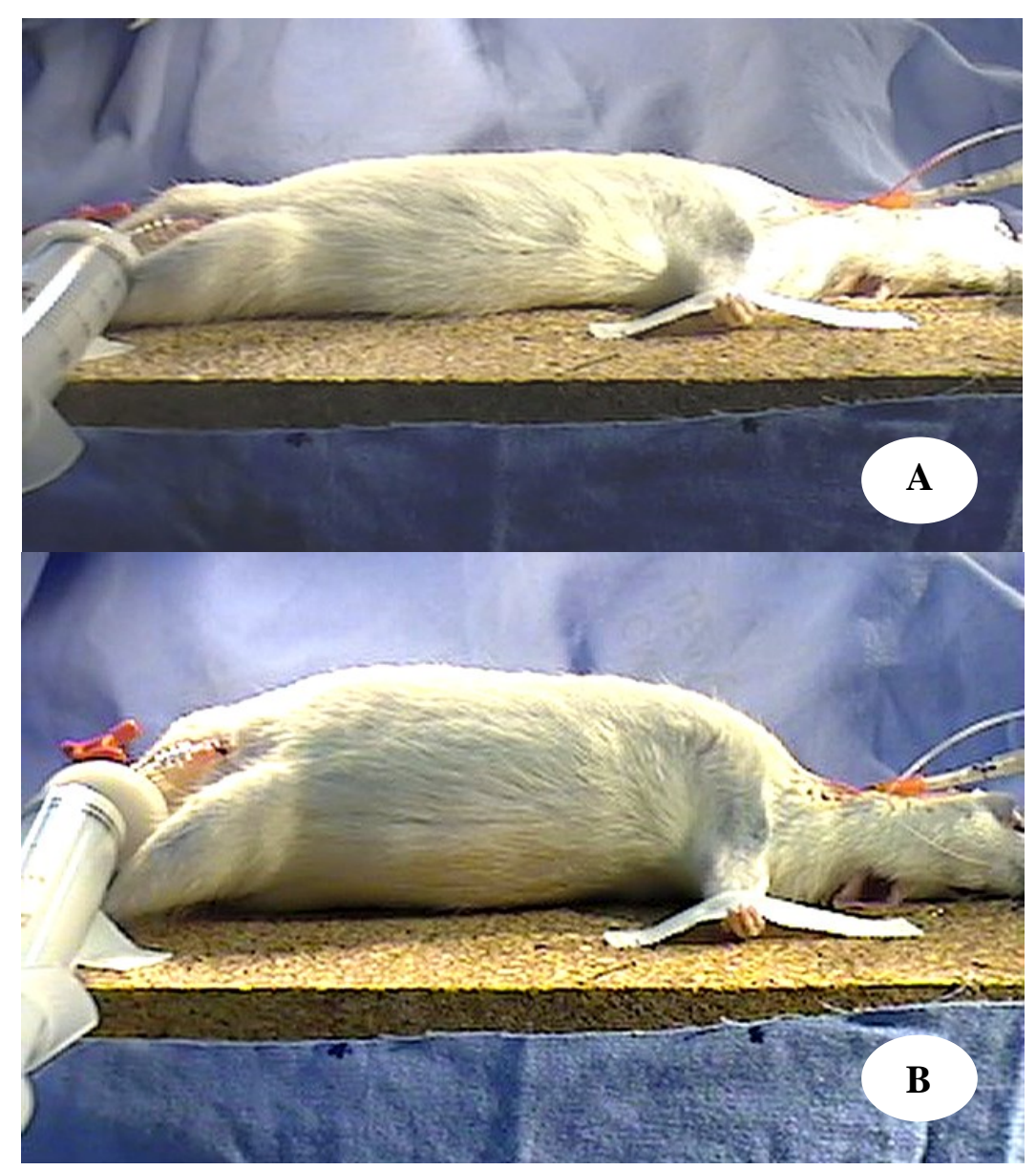

FIGURE 2 - Intra-abdominal hypertension. Same animal before (A) and after (B) the increase of the abdominal pressure to $25 \mathrm{mmHg}$.

Method description - Two Insult Model (Hemorrhagic Shock Followed by the Abdominal Compartment Syndrome)

This model involved the same procedures previously described up to number 5 .

\section{Surgical procedure before hemorrhagic shock}

The left jugular vein and the left femoral artery are cannulated with previously heparinized $10 \mathrm{~cm}$ long PE50 catheters which are exterionized through the back of the neck and thigh, respectively, using a 16G needle. This procedure is to prevent the animals from biting on the catheter.

\section{Monitoring}

Baseline MAP and blood gases are obtained and then MAP is continuously monitored throughout the hemonhagic shock phase using a digital monitor.

\section{Hemorrhagic shock}


Hemonhagic shock begins by the aspiration of $4 \mathrm{ml}$ of blood from the femoral artery catheter. Additional volumes are aspirated every five minutes to lower the MAP to $30 \mathrm{mmHg}$. Mean arterial pressure is maintained at this level for 45 minutes. Shed blood is stored in an incubator at $37^{\circ} \mathrm{C}$ inside sterile tubes.

\section{Volume resuscitation}

The animals are resuscitated with $33,2 \mathrm{ml} / \mathrm{kg}$ of $0.9 \%$ sodium chloride $(0.9 \% \mathrm{NaCl})$ solution plus $75 \%$ of the shed blood volume, mixed in a sterile tube. The total volume is infused in the left jugular vein catheter with an infusion pump during 60 minutes.

\section{Surgical procedure after hemorrhagic shock}

Ten minutes after beginning the resuscitation phase the animals undergo a $2 \mathrm{~cm}$ long midline laparotomy under aseptic technique. Two angiocatheters (14G) are placed through the abdominal wall, under direct vision, on each side of the midline (Figure 3). The catheters are occluded and anchored to the skin with a single 4-0 silk stitch each. A sterile seven inches latex balloon is placed inside the abdominal cavity (Figure 4). The open end of the balloon is exterionized through a midline counter-incision at the most distal portion of the laparotomy and anchored to the skin with a single 4-0 silk stitch. The midline laparotomy and the skin are closed with intemupted 4-0 silk sutures.

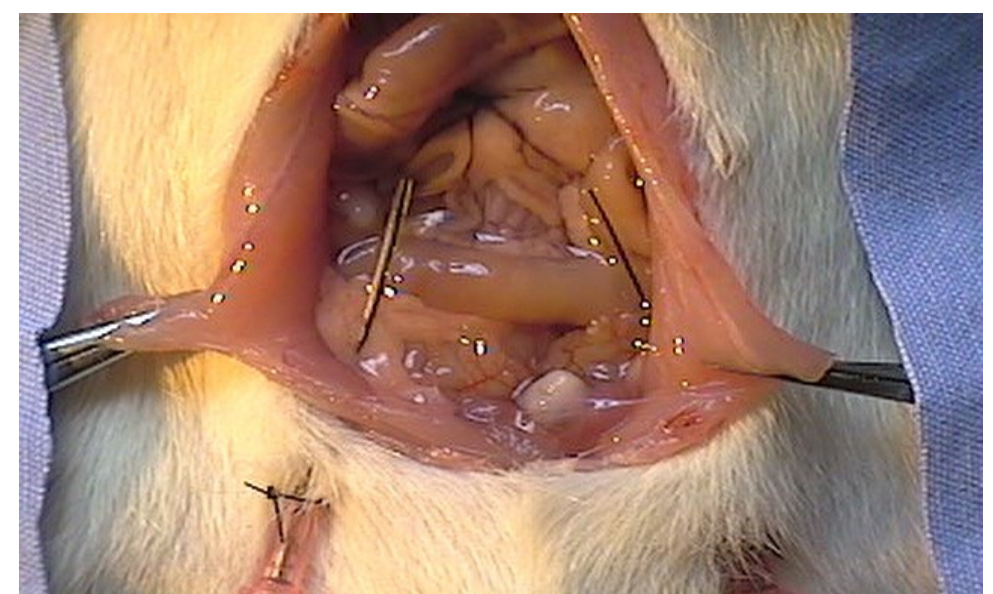

FIGURE 3 - Laparotomy showing catheter placement and fixation.

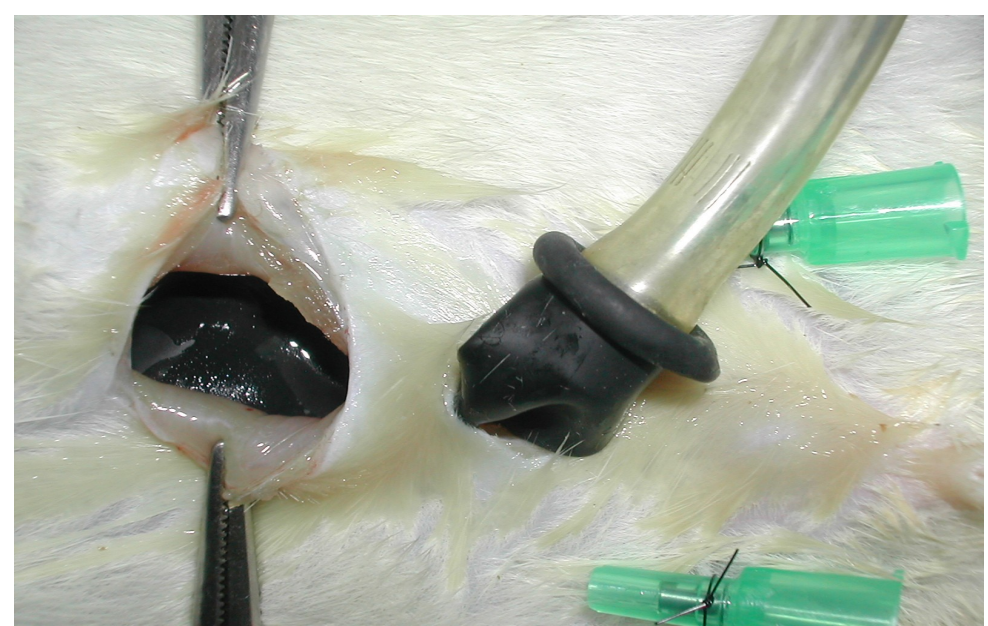

FIGURE 4 - Positioning of the latex balloon inside the abdominal cavity. 


\section{Post-operative analgesia}

After volume resuscitation the animals are placed in appropriate cages and receive food and water ad libitum. Acetaminophen is dissolved in water $(0.1 \mathrm{mg} /$ dose $)$ for postoperative analgesia, 24 hours following surgery.

\section{Anesthesia for intra-abdominal hypertension}

Two hours after the beginning of the hemonhagic shock phase the animals are again anesthetized as previously described.

\section{Endotracheal intubation}

The animals are placed on their backs with the neck in hyperextension. A light source is applied on the neck to visualize the tracheal lumen. The animal's tongue is grasped with a forceps and pulled to the outside and a spatula is used to visualize the glottis where a 16G angiocatheter $(1.5 \mathrm{~cm}$ long) is inserted under direct vision. The catheter is anchored to the central incisor with a 4-0 silk tie.

\section{Hemodynamic monitoring}

The vascular catheters and the abdominal catheter left of the midline are connected to the monitor.

\section{Mechanical ventilation}

The animals are mechanically ventilated as previously described.

\section{Intra-abdominal hypertension as the second insult}

Initially $15 \mathrm{ml}$ of air are added to the latex balloon with a device used to insufflate laparoscopic hemioplasty balloon. This air volume causes the latex balloon to occlude the laparotomy incision therefore preventing intra-abdominal air escape. Intra-abdominal pressure is increased by manual air injection, through the abdominal catheter positioned on the right side of the midline, by increments of $5 \mathrm{mmHg}$ every 10 minutes up to $25 \mathrm{mmHg}$. This final pressure is maintained for 60 minutes. A $0.9 \% \mathrm{NaCl}$ solution is continuously infused $(45 \mathrm{ml} / \mathrm{kg} / \mathrm{h})$ through the left jugular vein catheter during the intra-abdominal hypertension phase. The purpose for fluid infusion during this phase is to maintain MAP above or equal to $80 \mathrm{mmHg}$. This pressure is accepted as adequate endpoint in hemornhagic shock resuscitation. ${ }^{11}$

\section{Ventilator wean after the second insult}

Mechanical ventilation weaning and extubation are completed 10 minutes after abdominal decompression. The animals are placed in appropriate cages as previously described.

\section{Perspectives}

The lack of clinically relevant experimental models to study the relationship between trauma and the systemic inflammatory response syndrome (SIRS) jeopardizes this field of research. There are significant drawbacks in models that provoke SIRS by injections of bacterial components, toxins and other substances. Those approaches create an artificial environment that bypasses the staged development of SIRS, therefore loosing clinical significance. The experimental models described in this study provide adequate means to explore the immune consequences of the ACS and the systemic inflammatory response to other insults in a clinically relevant environment. 


\section{References}

1. Burch JM, Moore EE, Moore FA, Franciose R. The abdominal compartment syndrome. Surg Clin North Am 1996; 76:833-42.

2. Cheatham ML. Intra-abdominal hypertension and the abdominal compartment syndrome. New Horiz 1999; 7:96-115.

3. Harman PK, Kron IL, McLachlan HD, Freedlender AE, Nolan SP. Elevated intra-abdominal pressure and renal function. Ann Surg 1982; 196:594-7.

4. Saggi BH, Sugerman HJ, Ivatury RR, Bloomfield GL. Abdominal compartment syndrome. J Trauma 1998; 45:597-609.

5. Schein M, Wittmann DH, Aprahamian CC, Condon RE. The abdominal compartment syndrome: The physiological and clinical consequences of elevated intra-abdominal pressure. J Am Coll Surg 1995; 180:745-53.

6. Bellis CJ, Wangensteen $\mathrm{OH}$. Venous circulatory changes in the abdomen and lower extremities attending intestinal distention. Proc Soc Exp Biol Med. 1939; 4:490-8.

7. Kron IL, Harman PK, Nolan SP. The measurement of intra-abdominal pressure as a criteria for abdominal re-exploration. Ann Surg. 1984;199:28-30.

8. Raebum CD, Moore EE, Biffl WL, Johnson JL, Meldrum DR, Offner PJ, Franciose RJ, Burch JM. The abdominal compartment syndrome is a morbid complication of post injury damage control surgery. Am $\mathrm{J}$ Surg 2001; 182:542-6.

9. Baue AE. The Concept of Limits and Emergence of Multiple Organ Failure. In: Faist E, Baue AE. The Immune Consequences of Trauma, Shock and Sepsis: Mechanisms and Therapeutic Approches. Berlin: Pabst Science Publishers; 1996: p.20-8.

10. Rezende-Neto JB, Moore EE, Andrade MVM, Teixeira MM, Lisboa FA, Arantes RME, Souza DG, CunhaMelo JR. Systemic inflammatory response secondary to abdominal compartment syndrome: stage for multiple organ failure. J Trauma 2002; 53:1121-8.

11. Anderson RW, Vaslef SN. Shock: Causes and Management of Circulatory Collapse. In: Sabiston DC Jr., Lyerly HK. Textbook of Surgery: The Biological Basis of Modem Surgical Practice. $15^{\text {th }}$ ed. Philadelphia: WB Saunders; 1997: p.68-91. 
Rezende-Neto JB, Silva AL, Cunha-Melo JR. Modelo expenimental de síndrome de compartimento abdominal como insulto único e como um segundo insulto, em ratos. Acta Cir Bras [serial online] 2003 Vol 18 Edição Especial. Disponível em URL: http://www.scielo.br/acb.

RESUMO - Este artigo propõe o desenvolvimento de um modelo experimental, clinicamente relevante, de síndrome de compartimento abdominal como insulto único e como segundo insulto após choque hemorrágico. No modelo de insulto único, ratos Sprague-Dawley machos, anestesiados, sob monitorização invasiva da pressão venosa central, pressão arterial média e ventilação mecânica são submetidos a síndrome de compartimento abdominal $(25 \mathrm{mmHg})$ por 60 minutos através da injeção de ar na cavidade peritoneal. No modelo de dois insultos ratos Sprague-Dawley machos, anestesiados, sob monitorização invasiva da pressão arterial média, são submetidos a choque hemonágico (30 mmHg) por 45 minutos seguido de reposição volêmica com solução de cloreto de sódio a $0,9 \%$ (NaCl) $33,2 \mathrm{ml} / \mathrm{kg}$ mais $75 \%$ da sangria e laparotomia. Duas horas após o início do choque hemorrágico os animais são anestesiados, intubados por via orotraqueal, colocados em ventilação mecânica, monitorizados invasivamente (pressão arterial média) e submetidos à síndrome de compartimento abdominal. Nesta fase é administrada solução $\mathrm{NaCl} 0,9 \%$ a $45 \mathrm{ml} / \mathrm{kg} / \mathrm{h}$. A associação dos insultos, síndrome de compartimento abdominal e choque hemorrágico, proporciona modelo clinicamente relevante.

DESCRITORES - Modelo animal. Síndrome compartimento abdominal. Resposta inflamatória. Lesão pulmonar. Falência de múltiplos órgãos.

Comespondence:

Conflict of interest: none Finantial source: none

José Renan Cunha Melo

Departamento de Cinurgia - Faculdade de Medicina - UFMG

Av. Alfredo Balena 190

30130-100 Belo Honizonte - MG

jrcmelo@medicina.ufmg.br

Data do recebimento: $22 / 04 / 2003$

Data da revisão: $18 / 05 / 2003$

Data da aprovação: 28/07/2003 